\title{
PECULIARITIES OF INVESTIGATED CHARACTERISTICS OF LITHUANIAN PISTOL AND RIFLE SHOOTERS' TRAINING AND SPORT PERFORMANCE
}

\author{
Vaida Gulbinskienė, Antanas Skarbalius \\ Lithuanian Academy of Physical Education, Kaunas, Lithuania
}

\begin{abstract}
Vaida Gulbinskienè. PhD in Social Sciences. Lecturer of Sports Games Department, researcher at the Laboratory of Sport Performance
\end{abstract} Monitoring, Lithuanian Academy of Physical Education. Research interests - modeling of training and sport performance.

\begin{abstract}
The purpose was to identify the peculiarities of selected training and sport performance characteristics: 1. training strategies, 2. the body sway and 3. mental fitness. Methods: we analysed the sport performance and training characteristics and applied interviews with elite and Lithuanian shooters. The body sway was studied applying the method of static posturography. The subjects were standing in four postures. Mental fitness of the shooters was evaluated $30 \mathrm{~min}$ before the start using CSAI-2 methodology and adapted SCAT methodology. The shooters were divided into two groups according to their sports performance: the high and the moderate mastery groups. Statistical analyses was made applying the SPSS 11.0 statistical package.

Results: 1. The Lithuanian women pistol shooters' mean age of the first three place winners corresponded to that of the elite athletes, however the sports results $(p<0.001)$ were significantly lower. We indicated the following reasons: they trained less than the elite shooters, their specific training was inappropriate $(p<0.001)$, their mental fitness and competition experience were inappropriate $(p<0.001)$. 2. The trajectory of the COP in a specific posture (legs at shoulder length, arms down; posture without the pistol; posture with the pistol) was significantly $(p<0.05)$ different (Fig. 1, Masalskyte et al., 2002) between high and moderate mastery shooters but not in general posture (folded legs and arms down). The results suggested developing shooters 'posture from the very beginning of training. 3. The Lithuanian shooters' level of anxiety before the starts showed the importance of the duration of exercise and competition experience because the difference between their indices and those of elite shooters was significantly less $(p<0.001)$.

Conclusions: On the basis of sport performance as a multidimensional construct which requires to select the main factors of athlete trainability we conclude that Lithuanian pistol and rifle shooters need a training programme that improves posture stability; they should increase their international competitive experience and have to monitor sport fitness in order to manage psychological stress, and model a further training programme. Social conditions might be the main problem of the Lithuanian shooters to terminate their sport career too early.
\end{abstract}

Keywords: pistol, rifle, shooters'training, sport performance.

\section{INTRODUCTION}

$\mathrm{S}$ hooting can be described as a static sport requiring extreme precision. Research in pistol and rifle shooting is centred on the areas of body sway and aiming point fluctuation (Ball et al., 2003). However, conflicting results have been reported in research literature. Significant associations between body sway and pistol shooting performance were found there (Iskra et al., 1988; Mason et al., 1990). However, more attention has been paid to the examination of the relationship between postural balance and shooting accuracy among elite shooters (Era et al., 1996; Viitasalo et al., 2001; Ball et al., 2003; Mononen et al., 2003 a), and studies about the relationship between the body sway and different mastery pistol groups are not numerous.

The shooters' ability to achieve and maintain good postural stability depends on the psychological 
factors as well (Mononen et al., 2003 a). Researchers found significant results in pistol shooting scores after the three-month psychological and physical program (Quevedo, Sole, 1995). The shooting result depends on visualisation, the level of anxiety, confidence, and emotional reaction to the environment (Chakraverty, Babar, 1998; Dubier et al., 1999; Li et al., 1999; Viitasalo et al., 2001; Debois et al., 2003; Lenart, 2003; Mononen et al., 2003 a). However, it is still not clear if the lack of psychological skills causes the variation of shooting results independently on the athletes' mastery and the level of competition.

Future shooters should have perfect visual and movement coordination, good reaction, ability to concentrate and the ability to retain emotional balance. Depending on the required skills for this sport, the age of the beginners ranges from 12 to 15 years, specialization takes place at the age of $17-18$ years and high mastery is achieved approximately at the age of 24-30 years (Bompa, 1999). The shooters' annual training model consists of general training elements for athletes, however there are no studies concerning how the training model (the training content: load, intensity, amount, work and rest days, sessions per week, competitions (Каменски et al., 2001)) alters depending on the number and the tasks of micro cycles - methodological publications describe the practical sporting experience of shooting experts. Mostly Scandinavian scientists examined the shooting training problems (Viitasalo et al., 2001; Mononen et al., 2003 b). However, they analyzed only the influence of feedback information on sports performance, but there was no information about training loads.

The purpose of this study was to identify the peculiarities of the following training and sport performance characteristics: 1 . training strategies, 2. the body sway and 3. mental fitness.

\section{MATERIALS AND METHODS}

Training characteristics and sport performance content. The performed theoretical shooters' training analysis allowed to design the content of the contest (shooting result, fluctuation of hits, shot time, position peculiarities) of sport performance. The sport performance characteristics (the prize holders $(n=26)$ of the Lithuanian shooting team and personal championships $(2001-2006)$ and the winners $(n=11)$ of the international competitions since 2001 till 2006 Bavaria Cup, World shooting Cup, Pilzen Cup competitions, World and Europe shooting championships) and training characteristics (participants age; cases $=330$ ) from 1988 till 2005 (cases of results $=349$ ) of Lithuanian and elite shooters (Table 1) were analysed.

We also analysed interviews (http://pilkguns. com/interviews.shtml) of elite and Lithuanian shooters (Table 1). They provided information about the duration of sports, training program and methods.

Body sway in shooting. The indices describing the posture were evaluated: shift to $\mathrm{x}$ and $\mathrm{y}$ directions of the centre of mass pressure (COP), trace length of COP, fluctuation amplitude spectrum of COP. The body sway was studied by the method of static posturography (Nashner et al., 1982). The serial production dynamographic platform MA-1 together with the computer equipment was used for the analysis of registered signals. The subjects were standing stable on the dynamographic platform while their COP side fluctuations (to the direction $\mathrm{x}$ ) were registered together with the fluctuations forwards and backwards (to the direction y). The subjects were standing in four postures: folded legs and arms down; legs at shoulder length, arms down; posture without the pistol; posture with the pistol (Masalskyte et al.,

\begin{tabular}{|c|c|c|c|c|c|c|c|c|c|c|}
\hline \multirow[t]{3}{*}{$\begin{array}{l}\text { Table } 1 . \text { Number of } \\
\text { subjects }\end{array}$} & \multirow{2}{*}{\multicolumn{3}{|c|}{ Shooters and Guns }} & \multirow{3}{*}{$\begin{array}{c}\text { Sport } \\
\text { performance } \\
\text { content }\end{array}$} & \multirow{2}{*}{\multicolumn{2}{|c|}{$\begin{array}{c}\text { Training } \\
\text { characteristics }\end{array}$}} & \multirow{2}{*}{\multicolumn{2}{|c|}{$\begin{array}{c}\text { Mental fitness } \\
\text { Athletes' mastery }\end{array}$}} & \multirow{2}{*}{\multicolumn{2}{|c|}{$\begin{array}{c}\text { Body sway } \\
\text { Athletes' mastery }\end{array}$}} \\
\hline & & & & & & & & & & \\
\hline & & & & & Moderate & High & Moderate* & High** & Moderate & High \\
\hline \multirow{8}{*}{$\begin{array}{l}\text { Notes. *- shooters without } \\
\text { the experience of internatio- } \\
\text { nal competition or those par- } \\
\text { ticipating in them one time } \\
\text { a year; } * *-\text { shooters who } \\
\text { participated ( } 3-4 \text { times a } \\
\text { year) in the international } \\
\text { competitions (V. K.) and } \\
\text { those who won high places } \\
\text { (K. G. - } 7 \text { th place in the }\end{array}$} & \multirow{2}{*}{\multicolumn{2}{|c|}{ Pistol }} & female & 5 & 6 & 3 & 3 & 2 & 3 & 5 \\
\hline & & & male & 7 & 4 & 1 & 1 & - & 5 & 3 \\
\hline & Litinuaman & \multirow{2}{*}{ Rifle } & female & 5 & 2 & 2 & - & 1 & & \\
\hline & & & male & 9 & 5 & 4 & 7 & 2 & & \\
\hline & \multirow{4}{*}{ Elite } & \multirow{2}{*}{ Pistol } & female & 4 & - & 30 & & & & \\
\hline & & & male & 3 & - & 19 & & & & \\
\hline & & \multirow{2}{*}{ Rifle } & female & 2 & - & 5 & & & & \\
\hline & & & male & 5 & - & 9 & & & & \\
\hline
\end{tabular}


2002). Aiming to determine the impact of the sight component to the posture (Giacomini et al., 1998), posturograma was registered when the subjects' eyes were open and closed. The discretization of the registered signal was $10 \mathrm{~ms}$. The duration of the posturograma registration was $60 \mathrm{~s}$. The shooting result was determined during the control practice, after the shooters' two series of ten shots. The shooters age was from 15 to 23 years. The shooters were divided into two groups according to their sports performance: the high mastery and the moderate mastery groups.

Mental fitness. Mental fitness of the shooters (Table 1) was evaluated 30 min (Craft et al., $2003)$ before the start $\left(\mathrm{n}_{\mathrm{Lithuanian}}=4 ; \mathrm{n}_{\text {international }}\right.$ $=3$ ) by $C S A I-2$ methodology, and by adapted (Gulbinskienè et al., 2007) SCAT methodology (Martens, 1977; Morrow et al., 2000).

Statistical analyses. The SPSS 11.0 statistical package was used for data analysis. The methods applied were means and standard deviation (SD). The differences between the groups were examined using non-parametric Wilkoxon, KolmogorovSmirnov Z tests and parametric Student criterion (TTest function). Statistical significance was accepted at the 95\% confidence level.

\section{RESULTS}

Training characteristics and sport performance content. The mean results of the first eight women pistol shooters of the last three Olympic Games (OG) and World championships (WCh) were very high and rather similar (air pistol $\mathrm{OG}=483.5 \pm 1.11$, $\mathrm{WCh}=482.8 \pm 0.78$; sport pistol OG $=785.6 \pm 6.82$; sport pistol $\mathrm{WCh}=784.3 \pm 4.88)$. The mean age of women pistol finalists was $31.0 \pm 1.0$ years at the $\mathrm{OG}$ and $30.8 \pm 1.93$ years at the WCh.
The mean age of Lithuanian women pistol shooters $(29.6 \pm 2.99$ year $)$ who won the first three places in 1998 - 2008 corresponds to that of elite athletes, however their results $(\mathrm{p}<0.001)$ were significantly less.

The researched elite athletes described their annual training cycle very diversely: some of them indicated the number of the days they trained annually and the number of shots they performed in the training sessions, others - the number of times and hours of training in a week (http:// pilkguns.com/interviews.shtml):

- The number of shots during the sessions of elite shooters ranged from 20 to 150 shots, it was influenced by the performance and period of training.

- The shooters had five to six training sessions in a week.

- The weekly training time was 21 and even more training hours and lasted for almost 300 days a year.

- A year after the Olympic Games in Athens and one year before the World shooting championship, the elite shooters participated in one to nine international competitions, where they started from two to 16 times (940 shots).

- One elite shooter, while training for the Olympic Games, carried out a four year Olympic cycle program.

- The others evaluated the world and continental championships and created longer or shorter programs.

It shows that training was modelled for every shooter individually.

Lithuanian moderate mastery shooters $(\mathrm{n}=17)$ took part in up to two international competitions and performed up to 100 shots. They had just two of three training sessions per week. Individual

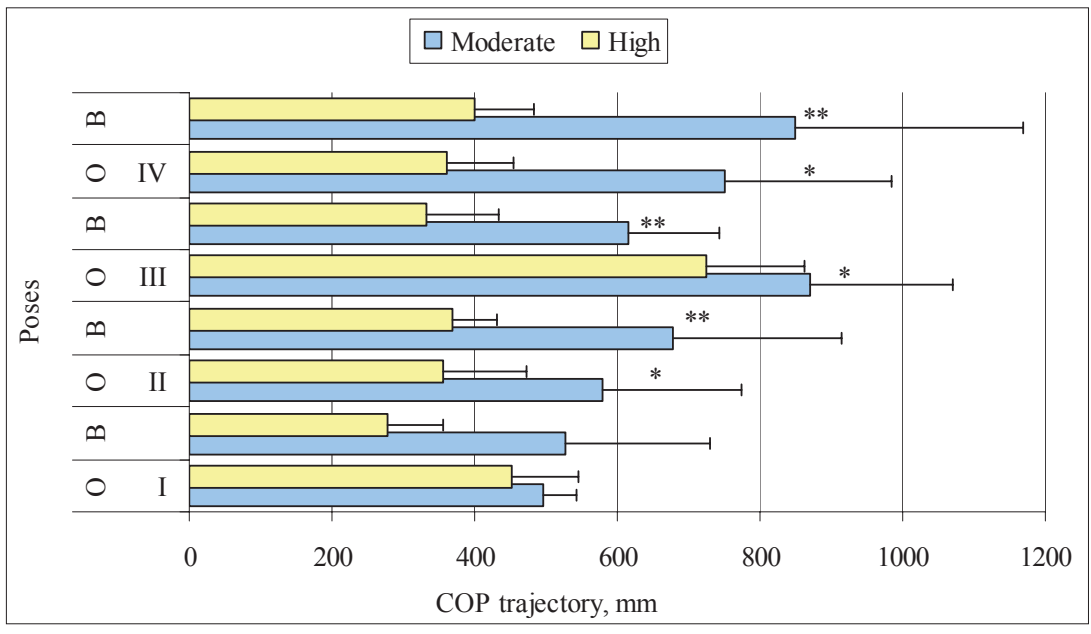

Fig. 1. The length of the shooters' COP trajectory (Mean \pm SD) (according to Masalskyte et al., 2002)
Note. Moderate - moderate mastery shooters' group; High — high mastery shooters; group; $\mathrm{O}-$ posture with open eyes; B — blindfold posture; * - p $<0.05 ; * *$ $\mathrm{p}<0.01$. 
Fig. 2. Mental fitness of the shooters (Mean \pm SD; Prior-competition, Cognitive, Somatic anxiety, Confidence) before the Lithuanian and International competitions Gulbinskiene et al., 2007)

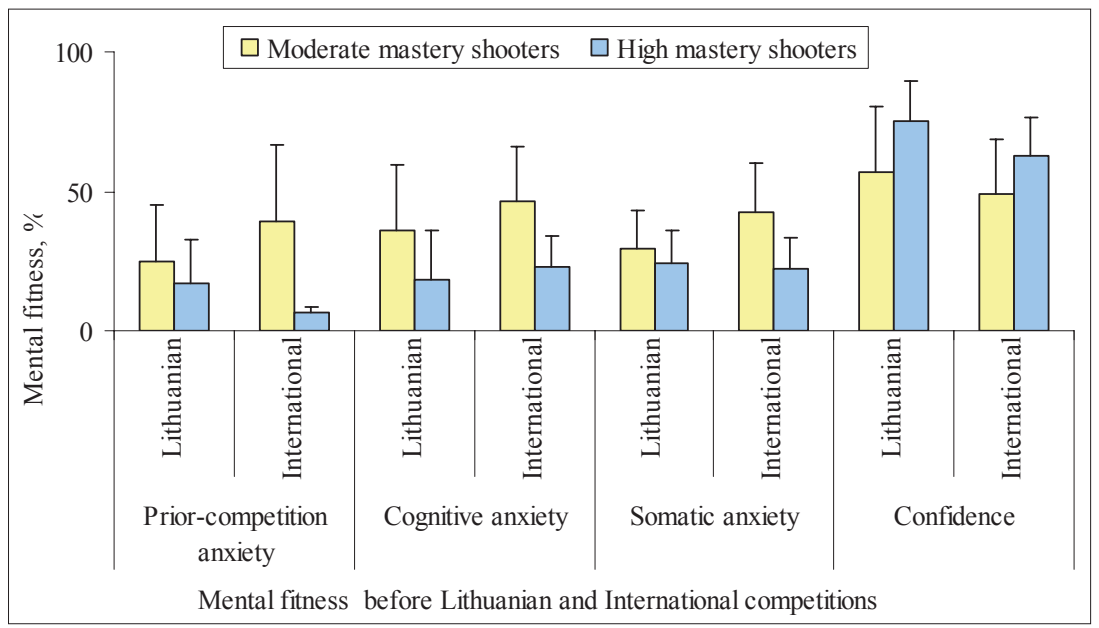

training programs were made only for high mastery shooters $(\mathrm{n}=10)$.

The studies showed that elite shooters' targeted training duration was quite different and it reflected the beginning of training being from 6 to 29 years of age, when the shooters started participating in the national team being from 13 to 30 years of age:

- elite shooters $(n=60)$ chose shooting at $14.48 \pm 4.53$ years of age,

- $4.24 \pm 3.52$ years after the beginning of sports activities, elite shooters began participating in the international competitions, i. e. at $18.83 \pm 5.05$ years of age $(n=23)$ and

- after 10 years, being $28.4 \pm 3.8$ years old $(\mathrm{n}=19$, athletes nominated as the shooters of the year) they achieved the greatest results.

Body sway in shooting. The trajectory of the COP in specific posture (legs at shoulder length, arms down; posture without the pistol; posture with the pistol) was significantly $(\mathrm{p}<0.05)$ different (Fig. 1, Masalskyte et al., 2002) between high and moderate mastery shooters but not in the general posture (folded legs and arms down).

In case of least support, the posture indices of the moderate and high mastery shooters with open eyes and blindfold are similar, but while turning to the typical posture with a gun, the posture indices of the high mastery shooters remained stable, while for moderate shooters it increased. Thus, the shooters' posture depends on the shooters' experience and it may be developed.

Mental fitness. The studied moderate mastery shooters felt greater anxiety before the starts at the Lithuanian and international competitions and less confidence than high mastery shooters (although significant differences were not found, Fig. 2).

High mastery shooters achieved significantly better results in the international competitions $(\mathrm{p}<0.05)$ than moderate mastery shooters. It allows stating that the duration of exercise, competition experience (Masalskyte, Skarbalius, 2003) let achieve better results and increase the shooters' self-confidence and, depending on the performance of the shooter (Avanesianas, 2003), allows managing their conditions before the start.

The fluctuation of the shooters' mental fitness was conditioned by their sport performance: moderate mastery shooters felt greater anxiety (prior to competition, cognitive, somatic) and lower self-confidence before international competitions than the high mastery shooters. That is why the significantly worse performance of Lithuanian shooters compared to elite shooters is explained by their mental fitness, which is conditioned by the insufficient experience at international competitions $(p<0.001)$. Thus, the shooter's mental fitness depends on the shooter's competition experience, and it may be developed.

\section{DISCUSSION}

Model of sport contest. No significant differences were found in the characteristics of shooters sport contest model between elite and Lithuanian athletes. Lithuanian shooters (in air and sport pistol events) showed lower results compared to the elite ones, except for the winners of Lithuanian championships (Masalskyte, Skarbalius, 2003).

Training features. Lower performance of Lithuanian shooters was caused by:

- less training volume than of the elite shooters;

- inappropriate specific training - the number of competition shots annually ( $\mathrm{p}<0.001$ ); 
- inappropriate mental fitness;

- insufficient competitive experience of international level $(\mathrm{p}<0.001)$.

Age of international shooters. More maturate shooters took part in the international competitions in the last decades of the $20^{\text {th }}$ century, and it did not change during the period of the last three Olympic games.

Body sway in shooting. The shooter's body sways, or the system "shooter-gun" stability, has been evaluated by the scientists while analyzing the way run of the COP and the amplitude using the Kistler power platform (Masalskyte et al., 2002), Scatt computer program, video camera (Ball et al., 2003; Mononen et al., 2003 a). P. Era and co-workers (1996) analyzed the posture of elite shooters and determined that it is most stable for one second until the shot is performed. The Lithuanian (Masalskyte et al., 2002) and foreign scientists (Era et al., 1996), who studied the shooters' posture, determined that the high and moderate mastery shooters' posture indices differed significantly. The Scandinavian scientists (Konttinen et al., 1998) researched the elite and moderate mastery shooters and determined that elite shooters tried to retain the posture in a proprioceptive way, while moderate mastery shooters - by sight. The studies suggest that the posture improved while providing information (feedback) about the posture and shooting result changes in the training process (Konttinen et al., $2004)$. On the bases of the difference $(p<0.05)$ of posture indices between high and moderate mastery shooters (Era et al.,1996; Masalskyte et al., 2002) we can claim that the postural stability develops during shooting training. It is known that interaction between elite shooters' posture indices and sport performance in not essential (Era et al., 1996), their posture is steady and does not influence their sport performance. However, the analysis of interaction of the Lithuanian shooters' posture and sport performance showed great negative $(\mathrm{r}=-0.95)$ correlation between the sport performance and the trajectory of the COP in shooters' posture with the pistol. It is recommended to emphasize training programme in order to improve posture stability and to enhance the sport performance.

Mental fitness. S. Hanton and co-workers (2000) examined the shooters' mental fitness and widely analyzed two psychological skills: confidence and ability to stabilize the emotional state. The visual creation method, as a way to improve the shooting technique and mental fitness, is recommended by the shooting experts (Chakraverty, Babar, 1998), scientists (Dubier et al., 1999) and elite shooters (Orlick, Partington, 1986). For some athletes, a high level of anxiety shows their good performance, while for others vice versa, they are recommended to calm down, because the psychological stress influences the central and peripheral sight negatively, while it has influence on the shooting result (Lee et al., 2000). Anxiety arouses various feelings in the shooters before the competitions. It has been determined that before the worse start there arise feelings related to competence: confidence and impeccability, while before the best start feelings related to emotions - good self-feeling and calmness (Debois et al., 2003). N. Li and coworkers (1999) determined, that the best shooting result was achieved when the level of anxiety was low, while the level of confidence - high, and they stated that anxiety and shooting results were related. A. Lenart (2003) ascertained a relation between the shooter's result and resistance to difficulty, orientation to success, resistance to anxiety $(\mathrm{p}<0.05)$. However V. Gulbinskiene with co-workers (2007) determined that the mental fitness of Lithuanian shooters depended on competitive experience. The competitive experience has significant influence on the possibility to achieve the highest sport performance, enhance self confidence and monitor the pre-competition state (Avanesianas, 2002; Jones, Hardy, 1988). The lower competitive experience $(p<0.001)$ is one of the reasons of worse sport performance.

\section{CONCLUSIONS}

On the basis of sport performance as a multidimensional construct which requires to select the main factors of athlete trainability we conclude that Lithuanian pistol and rifle shooters:

- need a training programme that improves posture stability;

- should increase international competitive experience;

- have to monitor sport fitness in order to manage psychological stress, and model a further training programme.

Social conditions might be the main problem of the Lithuanian shooters to terminate their sports career too early. 


\section{REFERENCES}

Avanesianas, G. (2003). Psichologiniai grį̌tamojo biologinio ryšio adekvatumo kriterijai modeliuojant sportinę veiklą. Sporto mokslas, 3 (33), 23-26.

Ball, K. A., Best, R. J., Wrigley, T. V. (2003). Inter- and intra-individual analysis in elite sport: Pistol shooting. Journal of Applied Biomechanics, 19 (1), 28-38.

Bompa, O. T. (1999). Periodization: Theory and Methodology of Training (Fourth edition). Champaign: Human Kinetics.

Chakraverty, S., Babar, A. S. (1998). Visualition. ISSF News International Shooting Sport, 1, 14-15.

Craft, L. L., Magyar, T. M., Becker, B. J., Feltz, D. L. (2003). The relationship between the competitive state anxiety inventory-2 and sport performance: A metaanalysis. Journal of Sport \& Exercise Psychology, 25, $44-65$.

Debois, N., d'Arripe-Longueville, F., Blondelot, M. (2003). Feeling states of elite shooters relative to their best and worst performances: A qualitative study: XI $I^{\text {th }}$ European Congress of Sport Psychology (pp. 47), Copenhagen, Denmark.

Dubier, J., Inchauspe, I., Tiberge, M. (1999). Stress regulation test through mental images on the French National Women Synchronized Swimming team during the 1998 Perth (Australia) World Championships. 5th IOC World Congress on Sport Sciences with the Annual Conference of Science and Medicine in Sport 1999. Internet link: http://www.ausport.gov.au/fulltext/1999/ iocwc/abs019b.htm

Era, P., Konttinen, N., Mehto, P. et al. (1996). Postural stability and skilled performance: A study on top-level and naive rifle shooters. Journal of Biomechanics, 29 (3), $301-306$.

Giacomini, P., Sorace, F., Margini, A. (1998). Alterations in postural control: The use of spectral analysis in stability measurement. Acta Otorhinolaryngol, 18 (2), 83-87.

Gulbinskienė, V., Malinauskas, R., Skarbalius, A. (2007). Šauliu psichinio parengtumo i̇vertinimas. Sporto mokslas, 2 (48), 27-30.

Hanton, S., Jones, G., Mullen, R. (2000). Intensity and direction of competitive state anxiety as interpreted by rugby players and rifle shooters. Perceptual and Motor Skills, 90 (2), 513-521.

Iskra, L., Gajewski, J., Wit, A. (1988). Spectral analysis of shooter-gun system. In G. DeGroot, P. A. Hollander, P. A. Huijing, G. J. Inger Scheanau (Eds.), Biomechanics $X I-B$ (pp. 914-919). Amsterdam: Free University Press.

Jones, J. G., Hardy, L. (1988). Stress and cognitive functioning in sport. Journal of Sport Sciences, 7, 4163.

Konttinen, N., Lyytinen, H., Viitasalo, J. (1998). Riflebalancing in precision shooting: Behavioral aspects and psychophysiological implication. Scandinavian Journal of Medicine and Science in Sports, 8 (2), 78-83.

Konttinen, N., Mets, T., Mononen, K., Viitasalo, J. (2004). The effects of augmented auditory feedback on postural stability and shooting accuracy in non-elite shooters. In Book of Abstracts of the $9^{\text {th }}$ Annual Congress of the European College of Sport Science (pp. 27), ClermontFerrand-France.
Lee, K. Y., Kim, Y. S., Cho, H. Y., Park, J. S. (2000). The effects of physical and psychological stressors on visual attention to the patterns of motor skills: 2000 Pre-Olympic Congress Sports Medicine and Physical Education International Congress on Sport Science, Brisbane, Australia. Internet link: http://www.ausport. gov.au/fulltext/2000/preoly/abs383a.htm

Lenart, A. (2003). Some technical and psychological factors of successful field crossbow shooting: Book of Abstracts of the 8th Annual Congress of the ECSS (pp. 116), Salzburg.

Li, N., Fan, Y., Guan X., Zhao, M. (1999). Research of precompetitive anxiety of shooting athletes: 5th IOC World Congress on Sport Sciences with the Annual Conference of Science and Medicine in Sport. Internet link: http://www.ausport.gov.au/fulltext/1999/iocwc/ abs073b.htm

Martens, R. (1977). Sport Competition Anxiety Test. Champaign, IL.: Human Kinetics.

Masalskyte, V., Muckus, K., Skarbalius, A. (2002). Ryšys tarp šaulių iš pistoleto meistriškumo ir jų pusiausvyros pastovumo. Ugdymas. Kūno kultūra. Sportas, 4 (45), $54-61$.

Masalskytė, V., Skarbalius A. (2003). Šaulès parengtumo kitimas rengiantis 2003 metu pasaulio taurès varžyboms. Ugdymas. Kūno kultūra. Sportas, 5 (50), 33-37.

Mason, B. R., Cowan, L. F., Gonczol, T. (1990). Factors affecting accuracy in pistol shooting. Excel, 6, 2-6.

Mononen, K., Viitasalo, J. T., Era, P., Konttinen, N. (2003 a). Optoelectronic measures in the analysis of running target shooting. Scandinavian Journal of Medicine \& Science in Sport, 13, 200-207.

Mononen, K., Viitasalo, J. T., Konttinen, N., Era, P. (2003 b). The effects of augmented kinematic feedback on motor skill learning in rifle shooting. Journal of Sports Sciences, 21, 867-876.

Morrow, J. R., Jackson, A. W., Disch, J. G., Mood, D. P. (2000). Measurement and Evaluation in Human Performance. Champaign: Human Kinetics.

Nashner, L. M., Black, F. O., Wall, C. (1982). Adaptation to altered support and visual conditions during stance: Patients with vestibular deficits. Journal of Neuroscience, 2 (5), 536-544.

Orlick, T., Partington, J. (1986). Linda Thom 1984 Olympic gold medalist - shooting. PSYCHED: Inner Views of Winning. Ottawa: Coaching Association of Canada.

Quevedo, L., Sole, J. (1995). Visual training programme applied to precision shooting. Ophthalmic and Physiological Optics, 15 (5), 519-523.

Viitasalo, J. T., Era, P., Konttinen, N. et al. (2001). Effect of 12-week shooting training and mode of feedback on shooting scores among novice shooters. Medicine and Science in Sports, 11, 362-368.

Каменски, В. Н., Вавилов, Ю. Н., Афанасьев, В. Н. (2001). Объём и интенсивность тренировочной нагрузки при стрельбе. Теория и практика физической культуры, 11, 33-34. 


\title{
LIETUVOS ŠAULIŲ (PISTOLETO IR ŠAUTUVO RUNGČIŲ) RENGIMO IR PARENGTUMO RODIKLIŲ YPATUMAI
}

\author{
Vaida Gulbinskienė, Antanas Skarbalius \\ Lietuvos kūno kultūros akademija, Kaunas, Lietuva
}

\begin{abstract}
SANTRAUKA
Tikslas - nustatyti Lietuvos didelio meistriškumo šaulių (pistoleto ir šautuvo rungčių) pasirinktu rodiklių (daugiamečio rengimo, rengimo krūvių; pusiausvyros; psichinio parengtumo) ypatumus.

Tyrimo metu analizuoti elito šaulių interviu, stebėta elito ir Lietuvos šaulių varžybinè veikla. Priešvaržybinis nerimas vertintas 30 min prieš startą CSAI-2 ir SCAT metodikomis, t. y. varžybinès būsenos ir varžybinio nerimo aprašais. Pusiausvyros stabilumas (KMC - kūno masès centro šoniniai svyravimai, svyravimai i priekị ir atgal. Buvo vertinta KMC šoninio poslinkio bei poslinkio pirmyn ir atgal didžiausioji verte; KMC trajektorijos ilgis tirtas statinès posturografijos metodu tiriamiesiems užimant keturias padètis. Skaičiavimai atlikti naudojantis SPSS 11.0 statistiniu paketu.

Lietuvos šaudymo čempionatų pistoleto rungties moteru grupèje prizininkių amžius atitiko elito šaulių, tačiau rezultatų skirtumas statistiškai reikšmingas $(\mathrm{p}<0,001)$. Ivertinus šaulių rengimo ypatumus nustatyti šie trūkumai: neadekvatus pratybų skaičius, nepakankamas specifinis rengimas $(p<0,001)$, nepakankamas psichinis parengtumas ir varžybinè patirtis $(\mathrm{p}<0,001)$.

Integralus pusiausvyros vertinimo rodiklis - KMC nueitas kelias - vidutinio ir didelio meistriškumo šaulių grupių statistiškai reikšmingai $(p<0,05)$ skyrèsi. Kai tiriamujų stovėsena buvo artima šauliams būdingai pozai, didelio meistriškumo šaulių pusiausvyros rodikliai išliko pastovūs, o vidutinio meistriškumo - didèjo. Vadinasi, šaulio pusiausvyra priklauso nuo patirties ir gali būti lavinama.

Vidutinio meistriškumo šaulių nerimo didèjimas, pasitikèjimo mažèjimas prieš tarptautines varžybas buvo labiau išreikštas nei didelio meistriškumo šaulių. Vadinasi, šaulio psichinis parengtumas priklauso nuo varžybinės patirties. Statistiškai reikšmingai blogesnį Lietuvos šauliu parengtumą nei elito šaulių apibūdina psichinis parengtumas, kurị lemia per menka tarptautiniu varžybų patirtis $(\mathrm{p}<0,001)$.

Kadangi sportininkų rengimas yra daugiaplanis vyksmas - būtina žinoti rodiklius, geriausiai apibūdinančius parengtumą. Tuo remdamiesi teigiame, kad Lietuvos šauliai (pistoleto ir šautuvo rungties) turètų daugiau lavinti pusiausvyrą, nuolatos stebèti, testuoti ir analizuoti sportini parengtumą norèdami tikslingai valdyti rengimąsi, varžybose patiriamą nerimą. Ankstyvą šaulių pasitraukimą iš sporto galèjo lemti socialinè aplinka.
\end{abstract}

Raktažodžiai: pistoletas, šautuvas, šaulių rengimas, parengtumas.

Gauta 2008 m. rugsèjo 8 d.

Received on September 8, 2008

Priimta 2008 m. gruodžio 9 d.

Accepted on December 9, 2008
Vaida Gulbinskiene

Lietuvos kūno kultūros akademija

(Lithuanian Academy of Physical Education)

Sporto g. 6, LT-44221 Kaunas

Lietuva (Lithuania)

Tel +37061215138

E-mail v.gulbinskiene@lkka.lt 